modbegreber, parallelbegreber og andre vigtige grundbegreber skal demonstrere begrebers sammenfiltrede, netværksagtige karakter, men som oftest bliver det ved antydningen. Det er næppe tilsigtet, men de mange korrigerende bemærkninger og afgrænsninger til andre begreber giver ind imellem en lidt steril fornemmelse af en semantisk linjedommer, der afgør hvornår det er relevant for os andre at tale om demokrati og hvornår det ikke er.

Men overfor denne mislyd er jeg selv i tvivl. Måske det ikke kan være anderledes? Måske er den solide historisme den eneste lødige pointe der kan være med til at ryste os i vor demokratiske selvtilstrækkelighed og i sandhed fremmedgøre os fra demokratibegrebet som sakrosankt selvbeskrivelse. I kraft af Nevers solide historisme er der med Fra skealdsord til slagord skabt et værk om det danske demokratibegreb der vil berige forskning og almindelig debat fremover. Tager man notits af bogens pointer, er alenlange forbindelseslinjer tilbage til en særlig demokratisk dansk fortid i den grad besværliggjorte fra nu af. Med Fra skecldsord til slagord gives læseren en omfattende mulighed for at få rekalibreret sin fornemmelse for betydningerne af begrebet 'demokrati'.
CARSTEN SESTOFT

\section{Sociologisk filosofihistorie af filosofisk sociolog}

Louis Pinto: La théorie souveraine. Les

philosophes français et la sociologie au

XXe siècle, Eds. du Cerf, 2009, 382

sider.

Forholdet mellem filosofi og sociologi det 20. århundredes Frankrig kan umiddelbart forekomme at være et marginalt og esoterisk emne. Louis Pintos bog belyser imidlertid på en både filosofisk og historisk måde nogle spørgsmål, som er væsentlige for mange humanistiske fag. Det gælder både mere overordnede temaer som forholdet mellem teori og empiri eller forholdet mellem filosofi og videnskab, og mere specifikke spørgsmål, eksempelvis forståelsen af Foucaults position.

Forsker, problematik og genstand er tæt sammenvævet i dette projekt. Da jeg i 1994 fulgte et kursus på Ecole des hautes études en sciences sociales hos Louis Pinto, stak Jacques Derrida en dag hovedet ind. Han havde reserveret lokalet til et møde og så sig derfor nødsaget til at hævde sin ret til det, hvad han gjorde på en yderst venlig måde. Med en vis ironiseret agtelse lod Pinto holdet vide, at når den store filosof ville til, måtte vi jo fortrække, og det gjorde vi så. Hans respekt for Derrida udsprang 
formentlig mindre af en dybfølt respekt for dennes filosofiske værk end for den filosofiunderviser, han en gang omkring 1970 havde haft på Ecole normale supérieure, og som siden var blevet verdensberømt, i hvert fald uden for Frankrig. Pinto vragede nemlig senere filosofien ved at vælge Pierre Bourdieu, som var Derridas studiekammerat fra samme Ecole normale supérieures filosofistudium omkring 1950, som læremester og ph.d.-vejleder.

Anekdoten siger lidt om, hvordan denne personlige og institutionelle sammenvævning (foruden det faktum, at Frankrigs intellektuelle liv helt konkret finder sted på 3-4 kvadratkilometer i Paris) gør sociologiens kritiske distance til filosofien til et kompliceret og paradoksalt projekt, som hæmmes af, at Pinto ikke selv er lige så kendt som dem, han skriver om. Hvis Bourdieu havde stået som afsender, ville bogen have haft en helt anden gennemslagskraft.

På et mere intellektuelt plan medfører den hierarkiforskel på filosofi (høj) og sociologi (lav), som på sin vis både er en indiskutabel kendsgerning og et polemisk udgangspunkt, at blandt dem, der kan læse bogen (dvs. har det tilstrækkelige teoretiske niveau), er der få, som vil: De, der kan følge den komplicerede og indimellem lidt indforståede fremstilling, er næppe særligt disponerede for at forstå den, eftersom refleksivitet ikke synes at være meget dyrket blandt yndere af nyere fransk filosofi, undtagen måske hvis interessen angår Foucaults historiske arbejder. Bogen kunne ellers fortjene stor udbredelse som et stærkt stykke idésociologi i Bourdieus ånd og som en kritisk gennemgang af fransk filosofi i nyere tid.

Pintos historie begynder omkring 1900 med Durkheim, der jo selv var uddannet filosof. De unge og dominerende filosoffer omkring tidsskriftet Revue de métaphysique et de morale (1895- ) søgte da at gøre filosofien mere professionel, dvs. mindre influeret af ideologier og religion, og var meget åbne over for den samtidige videnskabelige praksis. Det gjaldt også Durkheims sociologi, selv om der også var en del skepsis over for dens videnskabelige prætentioner og brud med filosofiske hierarkier (individets forrang for kollektivet eksempelvis). Med importen fra omkring 1920erne af diverse tyske filosofier - Husserl og Heidegger, Hegel, Dilthey og Scheler mfl. - blev filosofien mere principielt antividenskabelig og dermed også sociologifjendtlig, mens Durkheim-skolen langsomt uddøde uden at blive fornyet af nye teoretisk stærke humanvidenskabelige projekter. Filoso- 
fien sikrede sig samtidig gennem temaet om autrui en grundlagsrefleksion over socialiteten. Den store filosof, som formåede at samle de mange tråde i en verden, der også var præget af de store ideologier fascismen og kommunismen -, af 2. verdenskrig og senere af den kolde krig, blev Sartre. Situationen ændrede sig først omkring 1960 , hvor feltets konfiguration igen var blevet en anden, idet tre former for modstand mod Sartres dominans var opstået: filosoffer med kompetence inden for videnskaberne (den bachelard-canguilhemske videnskabsfilosofi og -historie), nye avancerede former for humanvidenskab (især Lévi-Strauss, men også historien med Febvre, Braudel, Vernant m.fl.) samt diverse avantgarder inden for litteraturkritikken. Én filosof havde kompetence inden for alle tre områder $\mathrm{og}$ dermed mulighed for at dominere det nye tværfaglige felt i 1960erne, nemlig Foucault. Vanskeligheden ved at holde sammen på de tre dele kan besigtiges i Foucaults Les Mots et les choses, hvis 'arkæologi' over humanvidenskaberne kan ses som et uforløst forsøg på at realisere den umulige sammenkobling af empirisk (historisk) forskning og ren tænkning. Bourdieus sociologiske projekt udsprang af samme konfiguration som Foucaults projekt, men kunne i sammenhængen ikke anerkendes som filosofisk og forblev derfor usynligt som sådan $i$ lange tider.

Et gennemgående tema gennem de tre perioder er, at filosofferne svinger mellem at forbeholde sig retten til at dømme om sociologiens grundlag i sidste instans og at udkaste projekter for en bedre sociologi end sociologernes. Selv i 60ernes og 70ernes karnevaleske tværfaglighed var filosofferne meget optaget af at opretholde grænsen mellem de empiriske videnskaber og den filosofiske spørgen til disse videnskabers grundlag og hensigter. Resultatet har været, at den franske filosofis bidrag til reel videnskab har bestået $i$ at gestikulere i retning af den uden selv at yde noget; eller i bedste fald, som hos Foucault, at iværksætte reel videnskab med temmelig uigennemskuelige forklaringer på, hvad han egentlig lavede - eksempelvis i Vidensarkæologien - selv om han i anden halvdel af 70 erne blev mere og mere tydelig omkring sit projekt.

Dette er blot de store linjer. Det interessante er egentlig mere analyserne af især de nyere filosoffer, fordi der her er tale om en ret enestående tilgang: Detaljerede diskussioner med en kritisk distance, som underbygges af både et omfattende kendskab til samtidens filosofiske felt og et reelt kendskab til de filosofiske tekster. Formentlig 
fordi jeg ikke selv er filosof, kan jeg godt lide Bourdieu-skolens måde at håndtere filosofi på - med en vis respektløs sans for kernen i sagen, som den fremstår ud fra en relationelt tænkende feltbetragtning, dvs. hvad der definerer et filosofisk projekt i forhold til andre intellektuelle projekter på samme tid.

Det er bogens styrke og svaghed, at dens ærinde er polemisk og apologetisk, fordi Bourdieu jo selv er en væsentlig position $\mathrm{i}$ det felts historie, som skal skrives. Styrken ligger i metoden, som selvsagt er bourdieusk, dvs. en feltanalytisk idéhistorie. Sådan en består ikke $i$ at sætte ideerne i kontekst, som når man forbinder noget indre med noget ydre: Det er at skrive historien om de sammenhænge, som findes $\mathrm{i}$ det sociale mikrokosmos - feltet - hvor ideerne bliver til. Det drejer sig altså hverken om at reducere ideer til sociale sammenhænge eller om at hævde, at ideer og sociale sammenhænge ikke kan tænkes hver for sig, men om at se, at ideer i sig selv udgør en form for sociale relationer, som filosofien og mere generelt universitetets teoristærke fag med deres tendens til "teorirealisme" behandler som uafhængige realiteter ved at løsrive dem fra både deres opståelsessammenhænge og fra sammenhænge, hvori de kunne reaktualiseres. Ved siden af forståelsen for feltets egenlogik er det desuden væsentligt at have øje for den måde, større historiske sammenhænge refrakteres ind i feltet, eksempelvis 2 . verdenskrig, kold krig, maj '68 etc.

Desuden udfolder han en virtuos kritik af især 60-70ernes radikale filosofi. At disse tankefigurer om subversion og transgression efter snart et halvt århundrede stadig er nutidens bedste bud på kritisk og politisk tænkning er i sig selv forbavsende nok; noget andet er manglen på refleksiv indsigt $\mathrm{i}$ den filosofiske aristokratisme, som de udtrykker: "De, som hyldede det nietzscheanske sublime ved det 'marginale' og det 'nomadiske', synes ikke at have stillet sig spørgsmålet om, hvorvidt det ikke var reserveret for en lille elite af 'frigjorte' intellektuelle" (s.319). Derved stillede de sig i vejen for en reel kollektiv refleksivitet, fordi de "forudsatte en universel tilslutning til de spil, som kun spilles af intellektuelle" (s.347).

Svagheden ved projektets udførelse ligger dels i, at Bourdieus position forekommer for lidt historiseret - som om historiseringen var en reduktion, der er forbeholdt fjenden - dels $i$ at andre synspunkter på udviklingen end ikke diskuteres. Eksempelvis har den Bourdieuog Foucault-inspirerede historiker Gérard Noiriel beskæftiget sig med historiografiens historie på måder, 
som klart overlapper med Pintos historie og problematik.

Selv om forfatteren ikke er særlig kendt uden for Paris, har han et solidt værk bag sig, siden han gik fra at være filosof til sociolog med specialisering i de intellektuelles og filosofiens sociologi. Han har bl.a. med tyve års mellemrum udgivet bøger om samtidens franske filosofi i sociologisk belysning, dels i Les philosophes entre le lycée et l'avantgarde (1987), dels i La Vocation et le métier de philosophe (2007). Den foreliggende bog minder dog mere om det store overblik, som han fremlagde i sin bog om Nietzschereceptionen i Frankrig i det tyvende århundrede, Les Neveux de Zarathoustra (1995), som jeg har anmeldt i K \& K $(78,1996)$.

NICOLAI VON EGGERS

\section{Sociologisk leksikon}

Steen Nepper Larsen \& Inge Kryger Pedersen (red.), Sociologisk leksikon, Hans Reitzels Forlag, 795 sider, 498 ker.

Når man bladrer i gennem Sociologisk Leksikon er det svært at få armene ned - selvom det er nødvendigt, hvis man vil bladre videre. Sociologisk Leksikon er ganske enkelt godt skrevet, godt disponeret og godt sat op. Artiklerne er som oftest omkring en tredjedel A4-side lange, men der findes opslag på op til to siders længde. Som det også bemærkes $\mathrm{i}$ forordet tager værket hermed både udfordringen fra Wikipedia og fra mere klassiske opslagsværker seriøst. Det medfører, at leksikonet er gennemført sociologisk i sine valg og sine vinklinger - hvorved det adskiller sig fra ethvert andet opslagsværk - og at leksikonets opslag i modsætning til Wikipedias på en gang er korte, skarpe, tankevækkende og præcise. At dette kan lade sig gøre beror udover kompetente bidrag og tekstredaktion på et for et opslagsværk særdeles modigt valg: I stedet for troskyldigt at opremse et hav af synspunkter på et givent begreb, præsenteres læseren fra starten for en (omend sober og åben) læsning. Eksempelvis starter opslaget 'Stat' med en definition fra Weber, suppleret af Bourdieu, går over en kort etymologi til en forlænget version af Foucaults statsgenealogi, inden vi slutter med tre perspektiver på nutidens nationalstat. Et andet eksempel er 'etnologi', hvor man i stedet for en klassisk videnskabelig selvforståelse, får slået fast, at etnologi er "udsprunget af 1800-tallets central- og nordeuropæiske nationaliseringsprocesser" i modsætning til antropologien, som er "udsprunget af koloniseringsprocesserne". Om det præcis hænger således sammen, skal jeg ikke gøre 